\title{
A comparative analysis on the binding characteristics of various mammalian albumins towards a multitherapeutic agent, pinostrobin
}

\author{
Shevin R. FEROZ, Rumana A. SUMI, Sri N.A. MALEK, and Saad TAYYAB \\ Biomolecular Research Group, Biochemistry Programme, Institute of Biological Sciences, Faculty of Science, \\ University of Malaya, 50603 Kuala Lumpur, Malaysia
}

\begin{abstract}
The interaction of pinostrobin (PS), a multitherapeutic agent with serum albumins of various mammalian species namely, goat, bovine, human, porcine, rabbit, sheep and dog was investigated using fluorescence quench titration and competitive drug displacement experiments. Analysis of the intrinsic fluorescence quenching data revealed values of the association constant, $K_{a}$ in the range of $1.49-6.12 \times 10^{4} \mathrm{M}^{-1}$, with 1:1 binding stoichiometry. Based on the PS-albumin binding characteristics, these albumins were grouped into two classes. Ligand displacement studies using warfarin as the site I marker ligand correlated well with the binding data. Albumins from goat and bovine were found to be closely similar to human albumin on the basis of PS binding characteristics.

Key words: animal model, drug-protein interaction, fluorescence spectroscopy, mammalian albumin, pinostrobin
\end{abstract}

\section{Introduction}

Animal models are immensely significant in drug discovery due to their importance in the characterization of disease pathophysiology, mechanism of drug action and identification of new biomarkers and drug targets [3,23]. Information gathered from such animal studies have proved vital in establishing pharmacodynamic/pharmacokinetic relationships, determining clinical dosing regimens, as well as assessing the toxicity and safety margin of a particular drug [5, 11]. Results of in vitro and cell/tissue-based systems are not entirely representative of an in vivo response, as the metabolism and disposition properties of a drug are not taken into consideration. Thus, animal testing represents an essential intermediary phase in drug development before a potential drug can be used for human trials.

Flavonoids have emerged as one of the most promis- ing drug candidates in recent times due to their medical significance in a wide range of diseases and ailments [9]. Furthermore, these flavonoids possess a large margin of safety as a result of their low toxicity in animals [14]. Pinostrobin (PS), a flavanone whose molecular structure is shown in Fig. 1, has been successfully tested as a potential anticancer agent based on its apoptotic activities on different cancer cell lines [20, 27, 28, 31]. In addition, PS has also been shown to confer other health benefits such as antiinflammatory [39], antiviral [38], antibacterial [22], antiulcerogenic [1] and antimutagenic [8] properties, to name a few.

As the most abundant plasma protein in the circulatory system, serum albumin functions as the main transport and depot protein for a vast variety of endogenous and exogenous ligands in the body [26]. It plays a critical role in the distribution, metabolism, efficacy and elimination of these molecules as they are significantly

(Received 26 June 2014 / Accepted 13 October 2014 / Published online in J-STAGE 16 December 2014)

Address corresponding: S. Tayyab, Biomolecular Research Group, Biochemistry Programme, Institute of Biological Sciences, Faculty of Science,

University of Malaya, 50603 Kuala Lumpur, Malaysia

(C)2015 Japanese Association for Laboratory Animal Science 
influenced by the nature and affinity of their interaction with albumin [26]. Thus, investigations into drug-albumin interactions are imperative in assessing the pharmacological potential of new drugs. Furthermore, before drug testing can be performed on human subjects, the safety and toxicity of a drug has to be evaluated using animal models that resemble as closely as possible to the human system in terms of the pharmacological aspects of drug-protein interaction. Species-dependent differences however, have been noticed with regard to the pharmacological response of various drugs/ligands $[2,4,32,34]$.

In the light of the above, we have investigated PS-albumin interaction with serum albumins from seven mammalian species, i.e., goat, bovine, human, porcine, rabbit, sheep and dog. The comparative data obtained from this study will be useful in developing an analogous model that could match certain attributes of the human system for clinical testing of new drugs.

\section{Materials and Methods}

\section{Materials}

Essentially fatty acid free serum albumins of goat (GSA), bovine (BSA), human (HSA), porcine (PSA), rabbit (RbSA), sheep (SSA) and dog (DSA); as well as warfarin (WFN) were purchased from Sigma-Aldrich Co. (St. Louis, MO). Pinostrobin (PS) was purified from Boesenbergia rotunda rhizomes following the published procedure [12] and its purity was established by NMR. All other chemicals used were of analytical grade purity.

\section{Analytical procedures}

Protein stock solutions were prepared in $10 \mathrm{mM}$ sodium phosphate buffer, $\mathrm{pH} 7.4$ and their concentrations except GSA and DSA were determined spectrophotometrically using $E_{1 \mathrm{~cm}}^{1 M}$ at $280 \mathrm{~nm}$ of $43,827 \mathrm{M}^{-1} \mathrm{~cm}^{-1}$ (BSA), 35,700 $\mathrm{M}^{-1} \mathrm{~cm}^{-1}$ (HSA), 43,385 $\mathrm{M}^{-1} \mathrm{~cm}^{-1}$ (PSA and RbSA), and $42,925 \mathrm{M}^{-1} \mathrm{~cm}^{-1}$ (SSA) [16]. The method of Lowry et al. [21] was employed to determine the concentrations of GSA and DSA stock solutions.

PS and WFN stock solutions were prepared by dissolving desired quantity of their crystals in $1 \mathrm{ml}$ of ethanol and methanol, respectively; followed by dilution with $10 \mathrm{mM}$ sodium phosphate buffer, $\mathrm{pH} 7.4$ to $100 \mathrm{ml}$. A molar extinction coefficient, $E_{\mathrm{lcm}}^{1 M}$ of $13,610 \mathrm{M}^{-1} \mathrm{~cm}^{-1}$ at $310 \mathrm{~nm}$ [36] was used to determine WFN concentration. All absorbance values were recorded on a Shi-

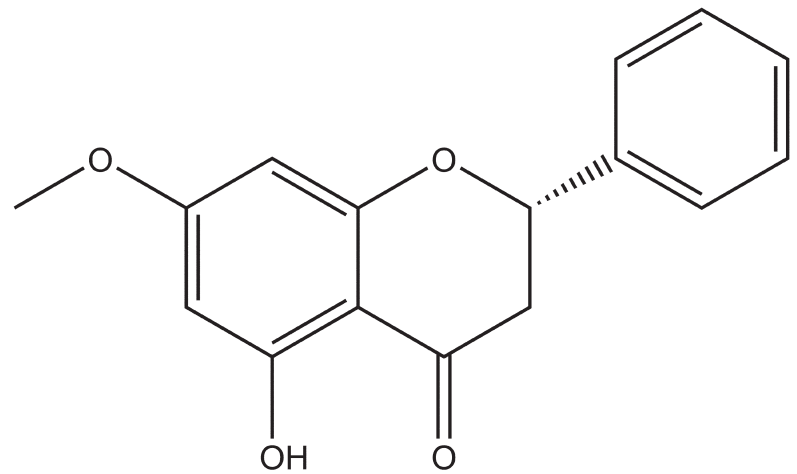

Fig. 1. Molecular structure of pinostrobin.

madzu UV-2450 double beam spectrophotometer (Shimadzu Corp., Kyoto, Japan) using quartz cuvettes of 1 $\mathrm{cm}$ path length.

\section{PS-albumin interaction}

The interactions between PS and various mammalian albumins were studied using fluorescence quench titration method as described earlier [12]. Increasing concentrations $(1.5-24 \mu \mathrm{M})$ of PS were added to a fixed protein concentration $(3 \mu \mathrm{M})$ in a total volume of $3 \mathrm{ml} .10 \mathrm{mM}$ sodium phosphate buffer was used to make up the volume to $3 \mathrm{~mL}$ and the incubation mixture was kept for $1 \mathrm{~h}$ at $25^{\circ} \mathrm{C}$. Fluorescence measurements were carried out on a Jasco FP-6500 spectrofluorometer (Jasco Corp., Tokyo, Japan) using a $1 \mathrm{~cm}$ path length quartz cell. The protein samples were excited at $280 \mathrm{~nm}$ and the emission spectra were recorded in the wavelength range, $300-380 \mathrm{~nm}$.

\section{Data analysis}

The values of the fluorescence intensity were first corrected for the inner filter effect according to the equation described by Lakowicz [19]:

$F_{c o r}=F_{o b s} 10^{\left(A_{e x}+A_{e m} / 2\right)}$

where $F_{c o r}$ and $F_{o b s}$ refer to the corrected and the observed fluorescence intensity values; while $A_{e x}$ and $A_{e m}$ are the changes in the absorbance of the samples at the excitation and emission wavelengths, respectively, produced by the addition of the ligand.

The corrected fluorescence data were then analyzed according to the following Stern-Volmer equation to determine the Stern-Volmer constant, $K_{S V}$ and the quenching mechanism involved in PS-albumin interaction [19]: 
$F_{0} / F=K_{S V}[Q]+1=k_{q} \tau_{0}[Q]+1$

where $F_{0}$ and $F$ are the fluorescence intensities in the absence and the presence of the quencher, respectively, $[Q]$ is the quencher (PS) concentration and $k_{q}$ is the bimolecular quenching constant. The value of $\tau_{0}$, the fluorophore lifetime in the absence of quencher for proteins was taken as $10^{-8} \mathrm{~s}$ [19], which is considered as a reasonable estimate of $\tau_{0}$ for proteins in general and has been used in many previous studies on ligand-albumin interactions $[10,17,30,35]$.

The values of the association constant, $K_{a}$ and $n$, the number of binding sites were obtained using the following equation [6]:

$\log \left(F_{0}-F\right) / F=n \log K_{a}-n \log \left[1 /\left(\left[L_{T}\right]-\left(F_{0}-F\right)\left[P_{T}\right] / F_{0}\right)\right]$

where $\left[L_{T}\right]$ and $\left[P_{T}\right]$ represent the total ligand concentration and total protein concentration, respectively. The values of $K_{a}$, thus obtained, were used to calculate the free energy change of the binding reaction, $\Delta G$ at temperature $T$, with the help of the following relationship:

$\Delta G=-R T \ln K_{a}$

A value of $8.3145 \mathrm{~J} \mathrm{~mol}^{-1} \mathrm{~K}^{-1}$ was used as the gas constant, $R$.

\section{Warfarin displacement studies}

Competitive displacement experiments using WFNalbumin complexes were performed by recording the fluorescence spectra of equimolar $(3 \mu \mathrm{M}) \mathrm{WFN}$-albumin complexes in the wavelength range, 360-450 nm upon excitation at $335 \mathrm{~nm}$, both in the absence and the presence of increasing PS concentrations (3-24 $\mu \mathrm{M})$. The WFN-albumin mixtures were incubated for $1 \mathrm{~h}$ prior to the addition of PS, followed by additional $1 \mathrm{~h}$ incubation before emission spectral measurements.

\section{Results and Discussion}

\section{PS-induced fluorescence quenching of serum albumins}

Many efforts to characterize the binding of a fluorescent macromolecule to its ligand have relied on fluorescence spectroscopy to shed light on the nature of the interaction. In the case of proteins, the intensity of its fluorescence signal is significantly affected as a result of interaction with other small molecules [19].

Figure 2 shows the fluorescence spectra of seven mam-

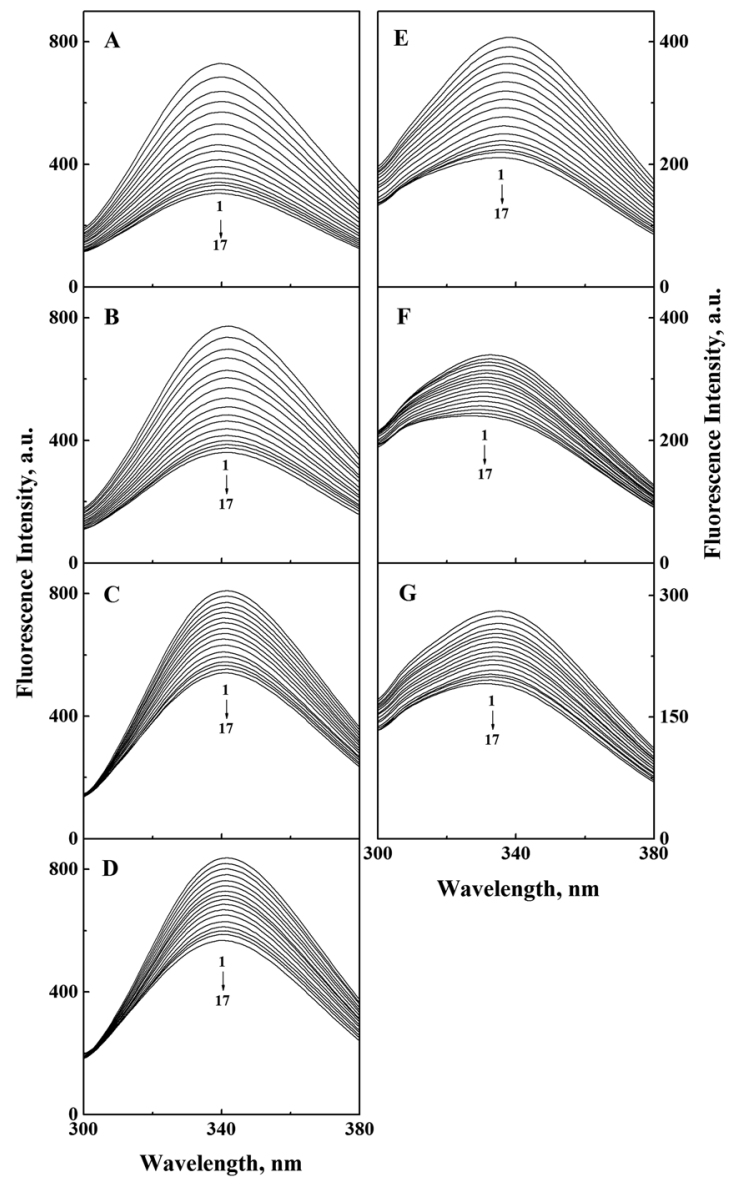

Fig. 2. Fluorescence spectra of different serum albumins with increasing pinostrobin (PS) concentrations. The spectra were obtained in $10 \mathrm{mM}$ sodium phosphate buffer, $\mathrm{pH}$ 7.4. [Albumin] $=3 \mu \mathrm{M},[\mathrm{PS}]=0-24 \mu \mathrm{M}$ with $1.5 \mu \mathrm{M}$ intervals $(1-17), \lambda_{\text {ex }}=280 \mathrm{~nm}, \mathrm{~T}=25$ ${ }^{\circ} \mathrm{C}$. (A) GSA, (B) BSA, (C) PSA, (D) SSA, (E) HSA, (F) DSA and (G) RbSA.

malian serum albumins ( $3 \mu \mathrm{M}$ each), namely, GSA, BSA, HSA, PSA, RbSA, SSA and DSA, recorded in the absence and the presence of increasing PS concentrations $(1.5-24 \mu \mathrm{M})$. The fluorescence properties of various albumins in terms of intensity and emission maximum, in their native form are listed in Table 1. As can be seen, the fluorescence intensity varied greatly among the proteins, following the order: $\mathrm{SSA}>\mathrm{PSA}>\mathrm{BSA}>\mathrm{GSA}>$ $\mathrm{HSA}>\mathrm{DSA}>\mathrm{RbSA}$, whereas the emission maximum was found to lie in the range, $333-342 \mathrm{~nm}$. These results were in line with the published results on the fluorescence characteristics of various serum albumins [16, 33]. It is well known that the main contributors to the fluorescence characteristics of a protein are the aromatic (mainly Trp and Tyr) amino acid residues [19]. Thus, 
Table 1. Fluorescence characteristics of different mammalian albumins in the absence and the presence of pinostrobin (PS)

\begin{tabular}{ccccc}
\hline Albumin & $\begin{array}{c}\text { Intensity } \\
\text { (a.u.) }\end{array}$ & $\begin{array}{c}\text { Emission maximum } \\
(\mathrm{nm})\end{array}$ & Trp residues $^{\mathrm{a}}$ & $\begin{array}{c}\text { [PS]:[Albumin] }=8: 1 \\
\text { \% Quenching }^{\mathrm{b}}\end{array}$ \\
\hline GSA & 729 & 340 & Trp-134, Trp-213 & $58 \pm 3.3$ \\
BSA & 773 & 342 & Trp-134, Trp-213 & $53 \pm 2.9$ \\
HSA & 407 & 338 & Trp-214 & $48 \pm 2.3$ \\
PSA & 810 & 341 & Trp-134, Trp-213 & $33 \pm 2.6$ \\
RbSA & 281 & 335 & Trp-214 & $32 \pm 2.8$ \\
SSA & 838 & 341 & Trp-134, Trp-213 & $32 \pm 2.9$ \\
DSA & 339 & 333 & Trp-214 & $30 \pm 2.7$ \\
\hline
\end{tabular}

a Obtained from the Univesal Protein Resource (Uniprot) database at www.uniprot.org.

${ }^{\mathrm{b}}$ Expressed as mean $\pm \mathrm{SD}$.

differences in the emission spectra of these albumins can be attributed to the number of Trp and/or Tyr residues and their location in the three-dimensional structure of the protein. However, in class B proteins, major contribution toward protein's fluorescence is due to Trp residues [19]. The details of Trp residues in terms of their number and location in the primary structure of these albumins are given in Table 1. It is interesting to note that location(s) of Trp residues is (are) remarkably well conserved among various animal albumins. As can be seen, proteins with two Trp residues (SSA, PSA, BSA and GSA) produced higher fluorescence intensities along with higher emission maxima compared to those with single Trp residue (Fig. 2 and Table 1).

Addition of increasing PS concentrations to the protein solution produced significant quenching of the protein's intrinsic fluorescence in all albumin species. A gradual decrease in the fluorescence intensity was observed in all albumins with the increase in PS concentration (Fig. 3). However, quantitative differences were noticed among these albumins. As evident from Fig. 3, decrease in the fluorescence intensity at 8:1 PS/albumin molar ratio was more pronounced for GSA (58\%), BSA (53\%) and HSA (48\%) compared to the rest of the albumins, showing $\sim 30 \%$ quenching (Table 1). Such quenching in the fluorescence intensity of albumins in the presence of PS was indicative of ligand-protein interaction [18].

\section{PS-albumin interaction: Quenching mechanism and binding parameters}

The quenching of protein fluorescence in the presence of a ligand (quencher) is known to involve either collisional or static quenching phenomena [19]. While the former refers to a process where the quencher interacts with the excited state of the fluorophore, the latter de- scribes a mechanism in which the formation of the fluorophore excited state is inhibited by ground state complexation between the ligand and the protein [7].

In order to characterize the mode of quenching involved in the interaction between PS and serum albumins, fluorescence quench titration data were analyzed according to the Stern-Volmer equation (Eq. 2). The Stern-Volmer plots, thus obtained with different PS-albumin systems are shown in Fig. 4A, while the values of the corresponding Stern-Volmer constants, $K_{S V}$ are listed in Table 2. An upward deviation in the SternVolmer plots was observed at higher PS concentrations (not shown), as has been reported in several earlier investigations on ligand-protein interactions $[13,24,25$, $29,37]$. Therefore, only those points falling in the initial linear zone were taken into account for regression analysis and $K_{S V}$ value determination. As the gradient of the Stern-Volmer plot, the value of $K_{S V}$ connotes the extent of quenching observed. Higher values of $K_{S V}$ obtained with GSA, BSA and HSA (Table 2) correlated well with the magnitude of quenching observed with these proteins at [PS]:[Albumin] molar ratio of 8:1 (Table 1). Values of $K_{S V}$ were used to determine the bimolecular quenching constant, $k_{q}$ for different PS-albumin systems according to Eq. 2 and were found to be in the order of $10^{12} \mathrm{M}^{-1} \mathrm{~s}^{-1}$. A collisional quenching process typically produces a value of $k_{q}$ in the region of $10^{10} \mathrm{M}^{-1} \mathrm{~s}^{-1}$, whereas the value of $k_{q}$ larger than this diffusion-controlled limit usually indicates a binding reaction [19]. In view of the higher values of $k_{q}\left(10^{12} \mathrm{M}^{-1} \mathrm{~s}^{-1}\right)$ obtained with different PS-albumin systems, it appears that the quenching process followed the static quenching mechanism, involving ligand-protein complex formation. We have already confirmed the phenomenon of static quenching in PS-HSA system based on inverse temper- 


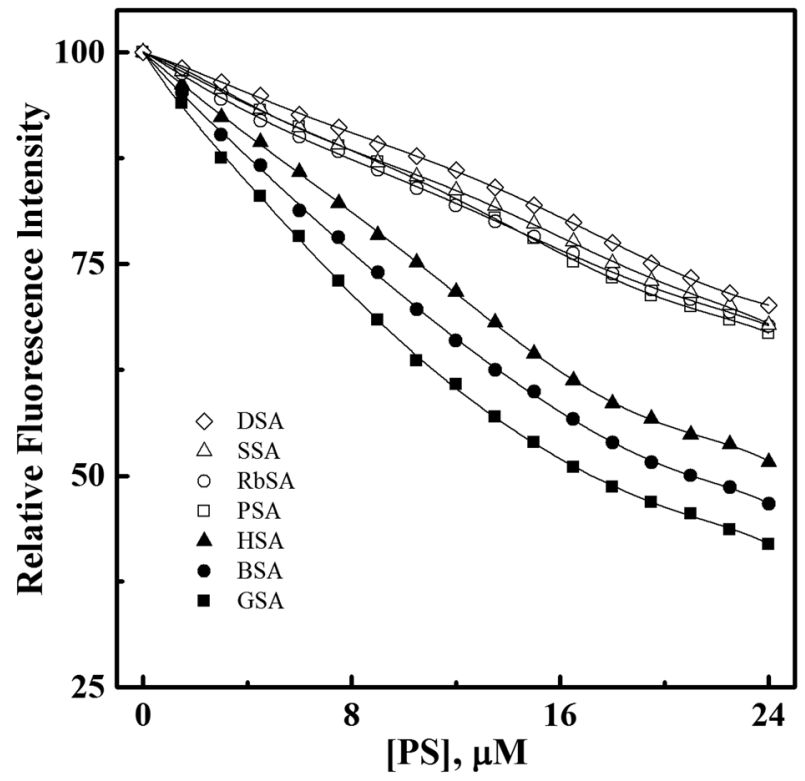

Fig. 3. Fluorescence quenching of albumins by pinostrobin (PS). Different plots show the decrease in the relative fluorescence intensity of different serum albumins at their emission maximum with increasing PS concentrations, as shown in Fig. 2.

ature-dependence in quenching studies [12].

Binding parameters in terms of the association constant, $K_{a}$ and the binding stoichiometry, $n$ for PS-albumin interaction were obtained after treating the fluorescence quenching data using Eq. 3. The use of this equation is advantageous over other methods of fluorescence data analysis due to the noninvolvement of any assumption with regard to the free and bound ligand concentrations [6]. The linear double logarithmic plots for different PS-albumin systems are shown in Fig. 4B and the values of $K_{a}$ and $n$, obtained from these plots are listed in Table 2. Based on the values of the association constant, different serum albumins used in this study can be classified into two distinct groups such as GSA, BSA and HSA with relatively higher PS binding affinity compared to the rest of the proteins, showing relatively lower $K_{a}$ values. Furthermore, GSA showed highest affinity whereas DSA was found to possess lowest binding affinity (Table 2). Interestingly, the value of $n$ for all PS-albumin complexes was found to be $\sim 1.0$, suggesting a 1:1 binding stoichiometry. The calculation of the free energy change $(\Delta G)$ of the binding reaction using Eq. 4 also suggested feasibility of the binding process as $\Delta G$ was found to vary within the range of -23.8 to $-27.3 \mathrm{~kJ}$ $\mathrm{mol}^{-1}$ (Table 2).
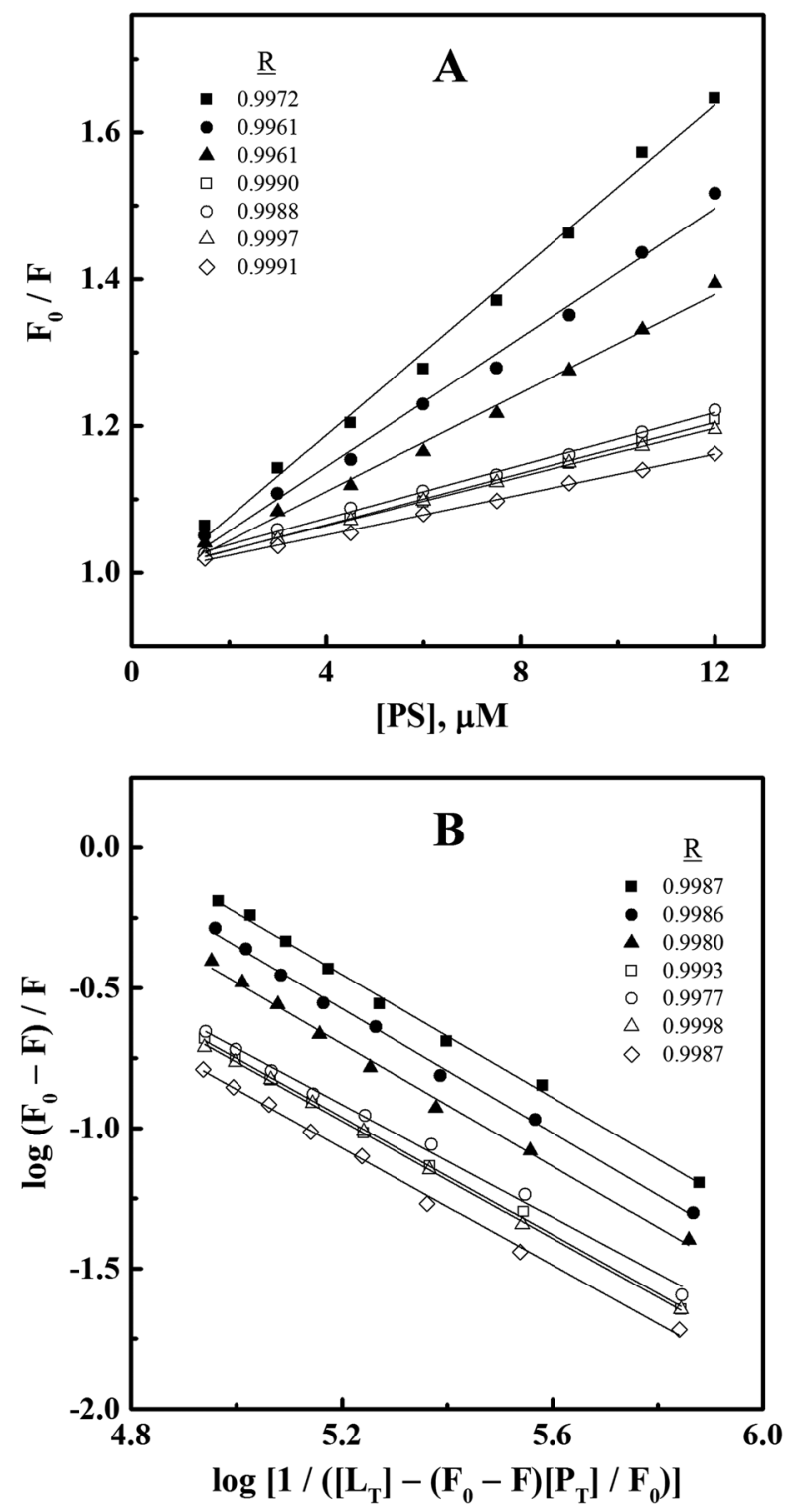

Fig. 4. Analysis of the fluorescence quench titration results. (A) Stern-Volmer plots and (B) double logarithmic plots of log $\left(F_{0}-F\right) / F$ versus $\log \left[1 /\left(\left[L_{T}\right]-\left(F_{0}-F\right)\left[P_{T}\right] / F_{0}\right)\right]$ for the interaction of pinostrobin (PS) to different serum albumins. The symbols used for different albumins are the same as shown in Fig. 3. Values of the correlation coefficient $(\mathrm{R})$ for different linear plots are shown against the symbols.

\section{PS-induced WFN displacement}

Recently we have shown Sudlow's site I as the preferred binding site of PS on HSA [12]. In the same investigation, we have clearly demonstrated insignificant binding of PS to Sudlow's site II, the other primary ligand binding site of HSA, even at high PS/HSA molar ratio. In view of the above, we extended our study to 
Table 2. Binding parameters for the interaction of pinostrobin (PS) with different mammalian albumins

\begin{tabular}{ccccc}
\hline Albumin & $K_{S V}\left(\mathrm{M}^{-1}\right)^{\mathrm{a}}$ & $K_{a}\left(\mathrm{M}^{-1}\right)^{\mathrm{a}}$ & $\mathrm{n}$ & $\Delta G\left(\mathrm{~kJ} \mathrm{~mol}^{-1}\right)$ \\
\hline GSA & $(5.62 \pm 0.35) \times 10^{4}$ & $(6.12 \pm 0.38) \times 10^{4}$ & 1.10 & -27.3 \\
BSA & $(4.40 \pm 0.31) \times 10^{4}$ & $(4.82 \pm 0.34) \times 10^{4}$ & 1.10 & -26.7 \\
HSA & $(3.36 \pm 0.24) \times 10^{4}$ & $(3.63 \pm 0.26) \times 10^{4}$ & 1.09 & -26.0 \\
PSA & $(1.75 \pm 0.22) \times 10^{4}$ & $(1.91 \pm 0.24) \times 10^{4}$ & 1.05 & -24.4 \\
RbSA & $(1.81 \pm 0.25) \times 10^{4}$ & $(1.95 \pm 0.27) \times 10^{4}$ & 1.00 & -24.5 \\
SSA & $(1.67 \pm 0.20) \times 10^{4}$ & $(1.86 \pm 0.22) \times 10^{4}$ & 1.05 & -24.4 \\
DSA & $(1.38 \pm 0.23) \times 10^{4}$ & $(1.49 \pm 0.25) \times 10^{4}$ & 1.04 & -23.8 \\
\hline
\end{tabular}

${ }^{\mathrm{a}}$ Expressed as mean $\pm \mathrm{SD}$.

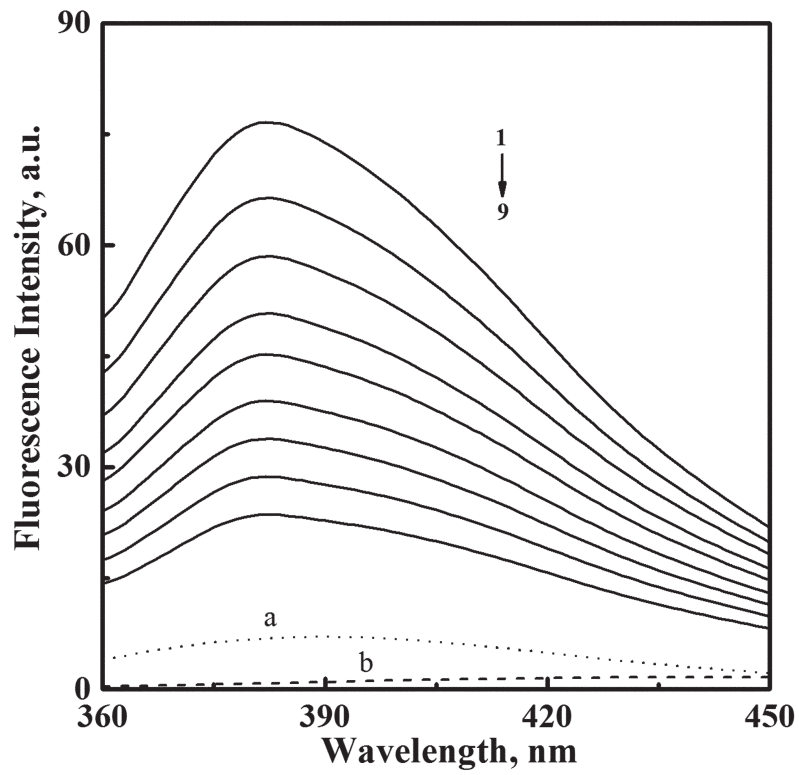

Fig. 5. Displacing effect of pinostrobin (PS) on the fluorescence spectrum of WFN-GSA complex. [GSA $]=[\mathrm{WFN}]=3$ $\mu \mathrm{M},[\mathrm{PS}]=0-24 \mu \mathrm{M}$ with $3 \mu \mathrm{M}$ intervals (1-9), $\lambda_{\text {ex }}=335$ $\mathrm{nm}, \mathrm{T}=25^{\circ} \mathrm{C}$. The spectra marked 'a' and ' $\mathrm{b}$ ' refer to the fluorescence spectra of $3 \mu \mathrm{M}$ WFN and $3 \mu \mathrm{M}$ GSA, respectively.

different serum albumins in order to substantiate our binding results, using WFN as a site I marker ligand. PS-induced WFN displacement from different WFN-albumin complexes was studied using fluorescence quenching. Figure 5 shows the effect of increasing PS concentrations on the fluorescence spectra of WFN-GSA complex. Qualitatively similar spectra were also obtained with other albumin complexes (figures are omitted for brevity). As shown in the figure, WFN-GSA complex produced the fluorescence spectrum in the wavelength range, $360-450 \mathrm{~nm}$ with an emission maximum at 383 $\mathrm{nm}$, upon excitation at $335 \mathrm{~nm}$. Addition of increasing PS concentrations to WFN-GSA complex, however, led

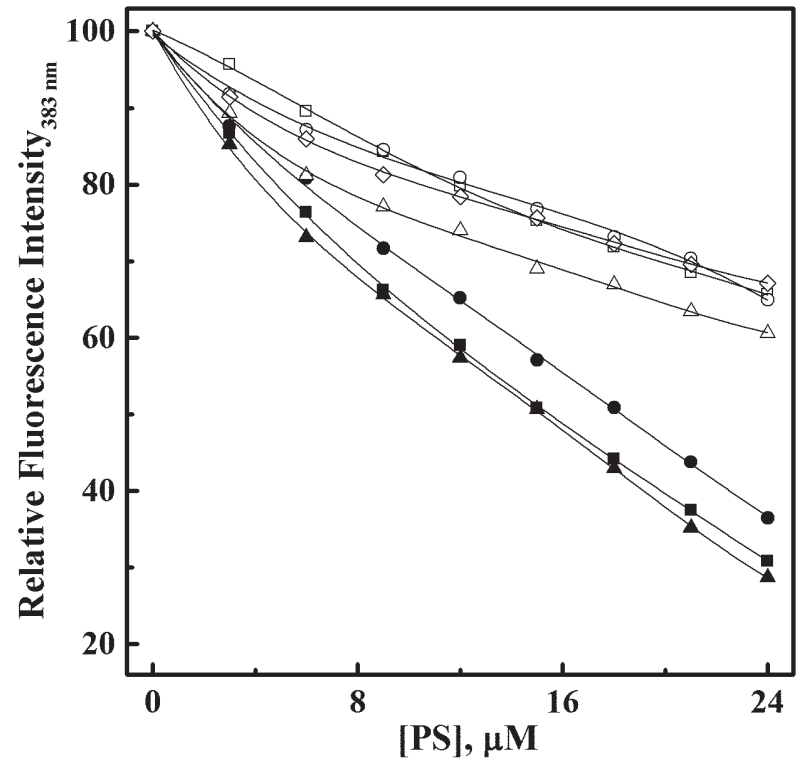

Fig. 6. Quenching of WFN-albumin complex fluorescence by pinostrobin (PS). Plots show the decrease in the relative fluorescence intensity of different WFN-albumin complexes at $383 \mathrm{~nm}$ with increasing PS concentrations. The symbols used for different albumins are the same as shown in Fig. 3.

to a progressive decrease in the fluorescence intensity, which was suggestive of the dissociation of WFN from its binding locus (site I) on the protein. It is important to note that both free WFN (spectrum a) and the albumin (spectrum b) solutions produced weak/insignificant fluorescence signals within this range.

These fluorescence data were transformed into relative fluorescence intensity at $383 \mathrm{~nm}$ by taking the fluorescence intensity value obtained in the absence of PS as 100 and plotted against PS concentration. Figure 6 depicts the decrease in the relative fluorescence intensity at $383 \mathrm{~nm}$ of different WFN-albumin complexes with increasing PS concentrations, while the values of the 
Table 3. Pinostrobin (PS)-induced WFN displacement from WFN-albumin complexes

\begin{tabular}{lc}
\hline Albumin & $\begin{array}{c}{[\mathrm{PS}]:[\text { Albumin] }=8: 1} \\
\% \text { Quenching }^{\mathrm{a}}\end{array}$ \\
\hline GSA & $69 \pm 3.0$ \\
BSA & $64 \pm 3.1$ \\
HSA & $71 \pm 2.7$ \\
PSA & $34 \pm 2.3$ \\
RbSA & $35 \pm 2.6$ \\
SSA & $39 \pm 2.2$ \\
DSA & $33 \pm 2.5$ \\
\hline
\end{tabular}

${ }^{\mathrm{a}}$ Expressed as mean $\pm \mathrm{SD}$.

percentage quenching achieved at the highest PS concentration (8:1 [PS]/[Albumin]) are listed in Table 3. While WFN-albumin complexes of GSA, BSA and HSA exhibited marked quenching (64-71\%) at 8:1 PS/albumin molar ratio, lesser quenching (33-39\%) was observed with other WFN-albumin complexes (Table 3). Interestingly, a striking positive correlation was observed between the affinity of PS towards albumin and its potential to displace WFN from Sudlow's site I. As shown in Table 2, GSA, BSA and HSA were also found to possess significantly larger $K_{a}$ values $\left(3.63-6.12 \times 10^{4} \mathrm{M}^{-1}\right)$ among the albumins studied. The slight variation in the quenching pattern observed within these two groups may be attributed to differences in the microenvironment of ligand binding sites in these albumins. In spite of the high sequence homology among various albumins, slight differences in their drug binding properties have been reported [15]. Thus, it is clear that the degrees of WFN displacement from site I by PS, observed with the various WFN-albumin complexes were largely dependent on the binding affinity of PS to albumins.

In conclusion, a comparison of the WFN displacement results and the binding parameters obtained with different mammalian albumins showed similarity in the PS binding characteristics of GSA and BSA with that of HSA. However, further in depth investigations on PSalbumin interaction are needed before reaching to a conclusion concerning the suitability of the animal model for pharmacological studies.

\section{Acknowledgments}

This work was financially supported by the High Impact Research MoE Grant UM.C/625/1/HIR/MoE/SC/02 approved by the Ministry of Education, Government of
Malaysia and the University of Malaya. The financial assistance from the University of Malaya to S.R.F. in the form of University of Malaya Postgraduate Research Fund (PG073/2013B) is highly appreciated. We thank the Dean, Faculty of Science and the Head, Institute of Biological Sciences, University of Malaya for providing the necessary facilities.

\section{References}

1. Abdelwahab, S.I., Mohan, S., Abdulla, M.A., Sukari, M.A., Abdul, A.B., Taha, M.M.E., Syam, S., Ahmad, S., and Lee, K.H. 2011. The methanolic extract of Boesenbergia rotunda (L.) Mansf. and its major compound pinostrobin induces anti-ulcerogenic property in vivo: possible involvement of indirect antioxidant action. J. Ethnopharmacol. 137: 963-970. [Medline] [CrossRef]

2. Aitken, M.M. 1983. Species differences in pharmacodynamics: some examples. Vet. Res. Commun. 7: 313-324. [Medline] [CrossRef]

3. Anderson, D.C. and Kodukula, K. 2014. Biomarkers in pharmacology and drug discovery. Biochem. Pharmacol. 87: 172-188. [Medline] [CrossRef]

4. Aubry, A.F., Markoglou, N., and McGann, A. 1995. Comparison of drug binding interactions on human, rat and rabbit serum albumin using high-performance displacement chromatography. Comp. Biochem. Physiol. C Pharmacol. Toxicol. Endocrinol. 112: 257-266. [Medline] [CrossRef]

5. Bass, A., Kinter, L., and Williams, P. 2004. Origins, practices and future of safety pharmacology. J. Pharmacol. Toxicol. Methods 49: 145-151. [Medline] [CrossRef]

6. Bi, S., Ding, L., Tian, Y., Song, D., Zhou, X., Liu, X., and Zhang, H. 2004. Investigation of the interaction between flavonoids and human serum albumin. J. Mol. Struct. 703: 37-45. [CrossRef]

7. Braslavsky, S.E. 2007. Glossary of terms used in photochemistry, 3rd edition (IUPAC Recommendations 2006). Pure Appl. Chem. 79: 293-465.

8. Charoensin, S., Punvittayagul, C., Pompimon, W., Mevatee, U., and Wongpoomchai, R. 2010. Toxicological and clastogenic evaluation of pinocembrin and pinostrobin isolated from Boesenbergia pandurata in Wistar rats. Thai. J. Toxicol. 25: 29-40.

9. Dangles, O. and Dufour, C. 2006. Flavonoid-protein interactions. pp. 443-464. In: Flavonoids: Chemistry, biochemistry, and applications. (Anderson, O. M., and Markham, K. R. eds.) CRC, Boca Raton.

10. Domínguez-García, M., Ortega-Zúñiga, C., and Meléndez, E. 2013. New tungstenocenes containing 3-hydroxy-4-pyrone ligands: antiproliferative activity on HT-29 and MCF-7 cell lines and binding to human serum albumin studied by fluorescence spectroscopy and molecular modeling methods. J. Biol. Inorg. Chem. 18: 195-209. [Medline] [CrossRef]

11. Fan, J. and de Lannoy, I.A.M. 2014. Pharmacokinetics. Biochem. Pharmacol. 87: 93-120. [Medline] [CrossRef]

12. Feroz, S.R., Mohamad, S.B., Bakri, Z.S.D., Malek, S.N.A., 
and Tayyab, S. 2013. Probing the interaction of a therapeutic flavonoid, pinostrobin with human serum albumin: multiple spectroscopic and molecular modeling investigations. PLoS ONE 8: e76067. [Medline] [CrossRef]

13. Feroz, S.R., Mohamad, S.B., Bujang, N., Malek, S.N.A., and Tayyab, S. 2012. Multispectroscopic and molecular modeling approach to investigate the interaction of flavokawain B with human serum albumin. J. Agric. Food Chem. 60: 58995908. [Medline] [CrossRef]

14. Havsteen, B.H. 2002. The biochemistry and medical significance of the flavonoids. Pharmacol. Ther. 96: 67-202. [Medline] [CrossRef]

15. Kaneko, K., Fukuda, H., Chuang, V.T.G., Yamasaki, K., Kawahara, K., Nakayama, H., Suenaga, A., Maruyama, T., and Otagiri, M. 2008. Subdomain IIIA of dog albumin contains a binding site similar to site II of human albumin. Drug Metab. Dispos. 36: 81-86. [Medline] [CrossRef]

16. Khan, J.M., Chaturvedi, S.K., and Khan, R.H. 2013. Elucidating the mode of action of urea on mammalian serum albumins and protective effect of sodium dodecyl sulfate. Biochem. Biophys. Res. Commun. 441: 681-688. [Medline] [CrossRef]

17. Khan, A.B., Khan, J.M., Ali, M.S., Khan, R.H., and Kabir-ud Din. 2011. Spectroscopic approach of the interaction study of amphiphilic drugs with the serum albumins. Colloids Surf. B Biointerfaces 87: 447-453. [Medline] [CrossRef]

18. Ladokhin, A.S. 2000. Fluorescence spectroscopy in peptide and protein analysis. pp. 5762-5779. In: Encyclopedia of analytical chemistry. (Meyers, R.A. ed.), Wiley, Chichester.

19. Lakowicz, J.R. 2006. Principles of Fluorescence Spectroscopy, 3rd ed., Plenum, New York.

20. Le Bail, J.C., Aubourg, L., and Habrioux, G. 2000. Effects of pinostrobin on estrogen metabolism and estrogen receptor transactivation. Cancer Lett. 156: 37-44. [Medline] [CrossRef]

21. Lowry, O.H., Rosebrough, N.J., Farr, A.L., and Randall, R.J. 1951. Protein measurement with the Folin phenol reagent. $J$. Biol. Chem. 193: 265-275. [Medline]

22. Mahady, G.B., Bhamarapravati, S., Adeniyi, B.A., Doyle, B., Locklear, T., Slover, C., and Pendland, S.L. 2006. Traditional Thai medicines inhibit Helicobacter pylori in vitro and in vivo: Support for ethnomedical use. Ethnobot. Res. Appl. 4: 159-165.

23. McGonigle, P. and Ruggeri, B. 2014. Animal models of human disease: challenges in enabling translation. Biochem. Pharmacol. 87: 162-171. [Medline] [CrossRef]

24. Pang, Y.H., Yang, L.L., Shuang, S.M., Dong, C., and Thompson, M. 2005. Interaction of human serum albumin with bendroflumethiazide studied by fluorescence spectroscopy. $J$. Photochem. Photobiol. B 80: 139-144. [Medline] [CrossRef]

25. Papadopoulou, A., Green, R.J., and Frazier, R.A. 2005. Interaction of flavonoids with bovine serum albumin: a fluorescence quenching study. J. Agric. Food Chem. 53: 158-163. [Medline] [CrossRef]

26. Peters, T. Jr. 1996. All about Albumin: Biochemistry, Genetics and Medical Applications, Academic, San Diego.

27. Poerwono, H., Sasaki, S., Hattori, Y., and Higashiyama,
K. 2010. Efficient microwave-assisted prenylation of pinostrobin and biological evaluation of its derivatives as antitumor agents. Bioorg. Med. Chem. Lett. 20: 2086-2089. [Medline] [CrossRef]

28. Smolarz, H.D., Mendyk, E., Bogucka-Kocka, A., and Kocki, J. 2006. Pinostrobin - an anti-leukemic flavonoid from $P_{O}$ lygonum lapathifolium L. ssp. nodosum (Pers.) Dans. Z. Naturforsch. C J. Biosci. 61: 64-68. [Medline]

29. Soares, S., Mateus, N., and Freitas, V. 2007. Interaction of different polyphenols with bovine serum albumin (BSA) and human salivary $\alpha$-amylase (HSA) by fluorescence quenching. J. Agric. Food Chem. 55: 6726-6735. [Medline] [CrossRef]

30. Solomonov, A.V., Rumyantsev, E.V., Ivanov, S.P., Kochergin, B.A., and Antina, E.V. 2013. Spectroscopic studies of the supramolecular interactions between uracil and 5-hydroxy6-methyluracil with bovine serum albumin and its bilirubin complex. Protein J. 32: 343-355. [Medline] [CrossRef]

31. Sukardiman, D., Darwanto, A., Tanjung, M., and Darmadi, M.O. 2000. Cytotoxic mechanism of flavonoid from Temu Kunci (Kaempferia pandurata) in cell culture of human mammary carcinoma. Clin. Hemorheol. Microcirc. 23: 185190. [Medline]

32. Tayyab, S. and Ali, M.K. 1997. Binding of bilirubin to mammalian erythrocytes. Comp. Biochem. Physiol. B Biochem. Mol. Biol. 118: 97-103. [Medline] [CrossRef]

33. Tayyab, S., Khan, N.J., Khan, M.A., and Kumar, Y. 2003. Behavior of various mammalian albumins towards bilirubin binding and photochemical properties of different bilirubinalbumin complexes. Int. J. Biol. Macromol. 31: 187-193. [Medline] [CrossRef]

34. Toutain, P.L., Ferran, A., and Bousquet-Mélou, A. 2010. Species differences in pharmacokinetics and pharmacodynamics. Handbook Exp. Pharmacol. 199: 19-48. [Medline] [CrossRef]

35. Tunç, S., Cetinkaya, A., and Duman, O. 2013. Spectroscopic investigations of the interactions of tramadol hydrochloride and 5-azacytidine drugs with human serum albumin and human hemoglobin proteins. J. Photochem. Photobiol. B 120: 59-65. [Medline] [CrossRef]

36. Twine, S.M., Gore, M.G., Morton, P., Fish, B.C., Lee, A.G., and East, J.M. 2003. Mechanism of binding of warfarin enantiomers to recombinant domains of human albumin. Arch. Biochem. Biophys. 414: 83-90. [Medline] [CrossRef]

37. Varlan, A. and Hillebrand, M. 2010. Bovine and human serum albumin interactions with 3-carboxyphenoxathiin studied by fluorescence and circular dichroism spectroscopy. Molecules 15: 3905-3919. [Medline] [CrossRef]

38. Wu, N., Kong, Y., Zu, Y., Fu, Y., Liu, Z., Meng, R., Liu, X., and Efferth, T. 2011. Activity investigation of pinostrobin towards herpes simplex virus- 1 as determined by atomic force microscopy. Phytomedicine 18: 110-118. [Medline] [CrossRef]

39. Wu, D., Nair, M.G., and DeWitt, D.L. 2002. Novel compounds from Piper methysticum Forst (Kava Kava) roots and their effect on cyclooxygenase enzyme. J. Agric. Food Chem. 50: 701-705. [Medline] [CrossRef] 